\title{
Professoras: narradoras de memórias e experiências do trabalho em escolas multisseriadas em Palmitos - SC
}

\author{
Elison Antonio Paim*
}

\begin{abstract}
Resumo
Na região Oeste de Santa Catarina, as atividades educacionais foram sendo formalizadas com o processo de colonização a partir do primeiro quartel do século XX. Nos primeiros tempos, as atividades educacionais aconteceram apenas em algumas comunidades nas quais pessoas de forma individualizada preocupavam-se com a escolarização. Em algumas comunidades, especialmente naquelas de descendentes de alemães, foram sendo construídas as primeiras salas de aula em que se ensinava em dialetos das línguas de origem, pois havia uma quase total ausência do Estado enquanto promotor da educação até a década de 1940. Com a Segunda Guerra Mundial, o governo brasileiro proibiu que os imigrantes e seus descendentes falassem em suas línguas e dialetos de origem. A partir de então, intensificaram-se as preocupações governamentais em dar uma educação mais formal para que, entre outras coisas, os alunos fossem ensinados a falar português. Nesta pesquisa, procuramos, mediante rememorações, dar visibilidade aos sujeitos realizadores da escolarização - os professores. Os dados foram obtidos mediante depoimentos orais de professoras no município de Palmitos, no estado de Santa Catarina.

Palavras-chave: memória, experiência, fazer-se professor, escolas multisseriadas.
\end{abstract}

Women teachers: memory and experience narrators of the work in multi seriated schools in Palmitos - SC

\begin{abstract}
In Santa Catarina's West region, the educational activities were formalized with the colonization process in the first quarter of the $20^{\text {th }}$ century. In the beginning the educational activities happened just in some communities in which individuals were worried about schooling. In some communities, mainly the ones of German descent, were built the first classrooms in which teaching was conveyed in the original languages dialects, because there was an almost full absence of The State as an educational promoter until the 1940s. With the World War II, the Brazilian government forbade the immigrants and their descendants to speak in their original languages and dialects. Since then, the perception of the growing importance of formal education led the government to the decision, among other things, of adopting teaching those students in Portuguese. In this research we aim, by means of recallings, to give visibility to the ones by whom this schooling was effected - the teachers. The data were got through oral statements from Palmitos municipal teachers in the state of Santa Catarina.

Key-words: memory, experience, became teacher, multi seriated schools.
\end{abstract}

\section{Algumas considerações iniciais}

Neste artigo, pelas rememorações, procuramos dar visibilidade aos sujeitos realizadores da escolarização - os professores. Com o projeto "Memórias e experiências do fazer-se professor (a) em escolas multisseriadas no Oeste de Santa Catarina", identificamos tempos, espaços e experiências formativas através das memórias dos sujeitos envolvidos em diferentes atividades educativas. O projeto foi desenvolvido inicialmente nos municípios catarinenses de Chapecó, Xaxim e Palmitos. Adotamos o procedimento do trabalho com fontes orais, como no subprojeto que será apresentado neste artigo evidenciando os professores residentes no município de Palmitos SC.

Por meio de algumas questões básicas

*Endereço eletrônico: elisonpaim@ hotmail.com enfocamos nos depoimentos como e por que estes professores assumiram as atividades docentes; qual a formação (ou sua ausência) desses sujeitos; como preparavam as aulas; o que ensinavam para cada série; quais as atividades assumidas junto às comunidades em que trabalharam, dentre outras.

A escolha dos depoentes centrou-se naqueles que viveram experiências de ensinar em escolas multisseriadas - aquelas com quatro ou duas séries iniciais do ensino fundamental em uma mesma sala de aula.

O principal instrumento de coleta de informações foram depoimentos orais, gravados com base nos procedimentos de história oral. Apresentamos algumas questões-chave semidirigidas para que pudessem dar início às falas, que estimulariam os depoentes a tecer comentários que julgassem relevantes a esta pesquisa. 
Não trabalhamos com a quantificação de depoimentos por entedermos que memórias são únicas e que, portanto, cada depoente terá uma forma única de rememorar. Porém, não pudemos coletar um número infinito de depoimentos e, assim, paramos no momento em que as informações foram se tornando aproximadas, possibilitando então a realização de cruzamentos, comparações e análises para a tessitura de narrativas.

Após a coleta gravada dos depoimentos, fizemos a transcrição e textualização para posterior análise, confronto com outras fontes e referencial teórico e, finalmente, a escrita do texto.

Nessa perspectiva rememorativa, a coleta das narrativas por meio da história oral é fundamental, pois vem se consolidando como recurso "para a realização de registros, documentos, arquivamento e estudos referentes à experiência social de pessoas e de grupos. Ela é sempre uma história do tempo presente e também reconhecida como história viva" (MEIHY; HOLANDA, 2007, p.17). Ainda segundo os autores, pelo fato de ser formada por vários aspectos, ela constitui uma história articulada por um conjunto de pessoas entrevistadas, e não apenas por uma única pessoa; pautam-se por planejamentos, definições de espaço e tempo, arquivamento, transcrições e autorizações para uso. Assim, essa perspectiva constitui não um simples diálogo gravado, mas um conjunto de fatores planejados, que visam a memorizar e responder a praticas sociais, políticas, culturais, econômicas e demais fatores do fato mencionado pelo depoente.

Neste subprojeto foram colhidos dados de seis professoras aposentadas residentes em Palmitos - SC, todas das quais trabalharam em escolas multisseriadas nesse município. A identificação das professoras, para a realização dos processos de colhimento da narrativa, deu-se mediante pessoas do município que as conheciam, apontando assim sua localização.

Os depoimentos tomados como rememorações mostram as experiências e o fazer-se professora das depoentes. Neste sentido, dialogamos com Edward Palmer Thompson, historiador inglês, quando pesquisou sobre a constituição da classe operária inglesa no século XVIII. Esse autor defende que a classe operária não nasceu pronta enquanto classe; ela se fez classe. Seu pensamento é basilar para pensarmos a constituição dos professores e não apenas sua formação como historicamente se costuma fazer. Entende-se o fazer-se professor como um processo permanente e continuo ao longo de toda uma vida em seus diferentes aspectos do sujeito professora.

\section{Memórias e Experiências}

Partimos do pressuposto de que a memória está sempre vinculada à lembrança e, evidentemente, ao esquecimento. Como lembrança e esquecimento formam uma unidade complementar e oposta, onde existir uma, lá estará a outra.

De acordo com Henry Bergson, as lembranças são espontâneas, revelam-se através de pequenos flashs que mostram um momento que já vivemos. Mas não aparecem realmente como aconteceram; elas são transformadas pelo presente e, portanto, reconstruídas. As lembranças não apenas trazem os acontecimentos ao presente como reconstroem, re-fazem as ações do passado, reconstruindo-os. A passagem da lembrança, do passado para o presente, pode ser individual ou coletiva. Ao lembrar, refazemos os atos do passado em relação ao tempo em que estamos lembrando, e podemos apoiar as lembranças individuais nas lembranças da sociedade. Assim, a constituição das lembranças ocorre também de forma coletiva, como lembra Chauí. Para esta autora, o ato de lembrar "não é reviver, mas re-fazer". Dessa forma, ao lembrar refletimos a partir do outrora, refazendo, revivendo, recriando, construindo com o nosso tempo e não simplesmente trazendo o vivido (CHAUÍ, 1978).

Mesmo sendo a memória individual, pois resultante do modo de vida de cada pessoa, Pinto (1998) diz que há combinações entre o individual e o coletivo, porque a memória individual encosta-se nas referencias coletiva, relacionando-as. Portanto, as lembranças do individuo podem interagir com as lembranças da comunidade, reforçando, caracterizando, inovando a lembrança dos fatos dentro da sociedade.

Ao falarmos de experiências relatadas pelas professoras, remetemos-nos diretamente ao que diz Thompson (1981, p. 182), ao defender que a sociedade deve ser entendida através das experiências, pois para ele "homens e mulheres experimentam sua experiência como sentimento e lidam com esses sentimentos na cultura, como normas, obrigações familiares e de parentesco, e reciprocidades". Considerar essas questões é fundamental para que possamos discutir a formação humana junto com os sujeitos, levando-se em consideração o que as formadoras/professoras pensam, como vivem, quais experiências têm para 
contar, que metodologias desenvolvem, quais as relações fazem entre teorias e práticas cotidianas.

Ao analisar as falas das professoras que atuaram no ensino em escola multisseriadas, observamos como essas profissionais rememoram a importância que tinham para a comunidade. Quando questionadas sobre sua participação em realizações da comunidade e da escola em prol dessas, afirmaram que realizavam tarefas extraclasse, ou seja, a vida nas comunidades estava centrada de uma maneira ou de outra nas professoras, pois estas estavam sempre à disposição das demandas comunitárias. Nesse sentido, Paim (2005, p.1) afirma que "as diferenças na forma de olhar para os professores estão vinculadas às formas de perceber o papel social da docência. O professor como agente social é "formado" para trabalhar numa perspectiva de manutenção da ordem estabelecida, ou de mudança e construção de um mundo melhor".

Analisando experiências, Gómez Pérez (2001, p.164) defende a existência de uma cultura docente, ou seja, os professores desenvolvem também elementos de uma cultura própria,

Como conjunto de crenças, valores, hábitos e normas dominantes que determinam o que este grupo social considera valioso em seu contexto profissional, assim como os modos politicamente corretos de pensar, de sentir, de atuar e se relacionar entre si (...) A cultura docente se especifica nos métodos que se utilizam na classe, na qualidade, no sentido e na orientação das relações inter pessoais, na definição de papéis e funções que desempenham, nos modos de gestão, nas estruturas de participação e nos processos de tomada de decisões.

Outra dimensão focalizada por Gomez Perez é a da cultura experiencial, através da qual abordou aspectos da experiência dos sujeitos, nos quais cada um desenvolve suas singularidades de forma individual, mas numa dimensão de coletividade: "o desenvolvimento da cultura experiencial de cada indivíduo é um compêndio singular de conteúdos e formas, de capacidades e sentimentos, atitudes e conhecimentos que se geram na concreta e peculiar interação evolutiva de cada sujeito com as peculiaridades, as pressões e as possibilidades, bem diferentes de cada cenário vital" (GÓMEZ PÉREZ, 2001, p. 256).

As professoras convidadas a narrar suas experiências revelaram um pouco da sua vida e o que as levou à docência e as diferentes formas de relações que tiveram com a escola e a sala de aula, muitas vezes assumindo as atividades educativas sem o devido preparo. Assim, ao iniciar as atividades foram fazendo-se professoras, pois revelaram que, conforme iam ministrando as aulas, iam aprendendo, aperfeiçoando-se. Dessa forma, remetemo-nos ao dialogo com a tese Memórias e Experiências do Fazer-se professor(a) desenvolvida por Paim (2005), quando trabalha numa perspectiva que considera a formação de professores como um processo contínuo, que ocorre ao longo de toda uma vida, e não apenas num dado momento ou lugar, o que nos leva a pensar na incompletude do ser humano e no seu eterno fazer-se.

As professoras depoentes, ao narrar aspectos de suas vidas, falaram das dificuldades e aprendizados que tiveram. Demonstraram ter autonomia, pois muitas vezes a escola, a alimentação, a limpeza e as atividades de sala de aula ficavam sob sua responsabilidade. Também demonstraram grande preocupação com o aprendizado dos alunos, que exigia preparo e conhecimento para o magistério nos ambientes referidos. Devido à exigência de preparo, os professores entrevistados relatam que procuraram aprimorar os conhecimentos, fazendo cursos de aperfeiçoamento e de magistério, assim como posteriormente o ensino superior. A experiência relatada por cada professora nos mostra que as metodologias, as estruturas das escolas eram heterogêneas, necessitando de diferentes perfis de professores, o que faz com que as experiências narradas caminhem na perspectiva do fazer-se professor, contrapondo-se à perspectiva da formação de professores, que nos remete à ideia de que formar alguém é definitivo.

As narrações das professoras nos possibilitam travar um diálogo com as concepções de memória, especialmente com Walter Benjamin e seus seguidores, pois, ao rememorar reconstruímos, buscamos nossas impressões mais remotas sobre o vivido por nós ou por aqueles que nos antecederam. Esse processo é sempre acionado por dimensões conscientes e inconscientes, despertadas no presente de quem rememora. Ao dialogar com essas rememorações busco reconstruções do passado desencadeadas pela situação presente - ou seja, as perguntas formuladas. As rememorações são eivadas simultaneamente de uma dimensão voluntária e outra involuntária. Esta última torna-se explícita quando, ao rememorar, esses sujeitos extrapolam o solicitado nas perguntas. 
Trabalhar com memórias significa colocarse na perspectiva oposta à de um tempo vazio e homogêneo - o linear -, substituindo-a por uma outra a qual possui um tempo saturado de 'agoras'. O agora, que é um confronto, possibilita fazer compreender o sentido da história.

As memórias, para Walter Benjamin, são plenas de conhecimentos e sensibilidades, relacionam-se com o vivido. Memória é também esquecimento, apaziguamento com o passado. A (re) memória é sempre relacionada com o presente, é um entrecruzamento de tempos, espaços, vozes; não é uma autobiografia no sentido clássico. É uma memória que não é só racional; é de um sujeito inteiro. Memória é vida, possibilidade da experiência vivida.

Benjamim nos dá ferramentas para percebermos que a produção historiográfica é um campo de lutas, em que diferentes concepções estão em constante disputa por espaços. Por outro lado, a percepção das lutas nos traz esperança de mudança e fornece instrumentos para esses embates. Conhecendo as lutas do passado entende-se o presente, porém mediante uma inversão de tempos, cujo ponto de partida são os agoras - dos problemas, buscando dialogar com o passado. Então, para o indivíduo, o conhecimento das lutas, das experiências do passado proporciona instrumentos e possibilita a esperança na mudança, na utopia como algo que está se fazendo.

\section{As origens}

O fazer-se docente para as professoras de escolas multisseriadas estava relacionado não apenas a sua construção profissional, mas à vontade de ensinar. De certa forma, havia uma idealização da vocação, ou seja, educar é compreendido como dom divino para a docência. Como podemos verificar na narrativa da professora Lucia. Assim:

Eu sempre amei essa profissão quando eu ia pra escola primeira a quarta serie adorava minha professora eu sempre adorei essa profissão achava que era uma missão bela importante. [...] Falava sempre para meus pais assim, um dia eu quero ser professora. Quando eu tinha 14 anos eu fui procurada por primos meus que pertenciam ao município de Irai. E lá eu fui trabalhar numa escolinha com 72 alunos. Eram 4 séries. $1^{\circ}$ e $2^{\circ}$ à tarde e $3^{\circ}$ e $4^{\circ}$ pela parte da manhã. (Cf. essa transcrição:

\section{pontuação)}

A influência de familiares professores foi marcante para que Salete decidisse ser professora, o que transparece quando afirmou: "Sei lá né, eu acho que além de gostar, a influencia também da minha família, minha avó, meus tios, irmãs da minha avó, os irmãos da minha mãe, as irmãs, todos foram professores. [...] todas elas foram professoras. Eu acho que é amor à profissão".

Por sua vez, Solange explicitou que em sua família ser professora era geracional, vejamos:

Foi por... Seguindo a profissão da família, meus bisavôs eram professores, minha avó foi professora, minha mãe foi professora, as tias todas, professoras. Então, na família não se pensava em outra coisa. Não tinha você pensa em segui, outra, profissão que era ser professora. Eu me criei... Desde que eu era menina eu pensava que ia ser professora e fui fazer magistério para ser professora. Na época também era assim, não tinha muitas opções de profissões para nós mulheres, que nós morávamos no interior, né? $E$ não ser professor. E em todas as comunidades tinha as escolinhas isoladas naquele tempo, então tinha vagas o suficiente para todo o pessoal que se formava.

\section{Alguns medos}

Embora houvesse certa idealização do que seria ser professora e desenvolver as atividades docentes, as professoras narradoras foram enfáticas ao expressar seus medos, tanto em relação à responsabilidade que estavam assumindo perante uma comunidade que lhes entregava seus filhos para serem escolarizados, quanto às condições para chegar até a escola ou estabelecer relações com a comunidade.

Ivani enfatizou sua apreensão em controlar, organizar a turma:

Assim, como que eu posso te dizer... Não ter domínio da classe, em primeiro lugar esse é meu medo maior, e assim números que na época a gente tinha todas as turmas juntas de $1^{\circ}$ a $4^{a}$. Então era de 48 para 50 alunos na mesma turma, né e não era fácil, a gente fazia lanche, cuidava da escola da limpeza, do pátio tu era tudo na escola, então a gente enfrentou muitos desafios no começo, reuniões com APP não tinha ninguém que te assessorava, uma vez por mês tu tinha 
uma reunião no município e o resto tinha que se virar sozinha.

Salete lembrou o medo que sentia ao se locomover até a escola atravessando matas, passando frio, assim como o receio de que as crianças não se alfabetizassem.

Eu tinha medo, pois onde eu passava tinha muito mato, ai eu fui dois anos a pé e depois quatro a cavalo. Então, eu tinha medo, passava frio, quantas vezes cheguei à escola com geada nas canelas. Porque, assim, seis, seis e meia tinha que sair de casa, eu tinha muito medo, meu Deus. E outra dificuldade é que eu me preocupava muito com os alunos, porque eu queria que eles apreendessem. Preocupava-me mais com os filhos dos outros do que com os meus. De noite ficava pensando porque aquele lá não aprende? Como vou fazer para solucionar aquele problema? Porque que aquele não aprende a ler? Daí chegava julho, agosto tinha aqueles que não tinham aprendido a ler. Então aquilo era preocupante para a gente. Preocupava-me muito com isso. [...] A única coisa que eu ficava triste, por exemplo, quando a primeira serie, não aprendia a ler né, eu ficava triste quando chegava ao final do ano e não aprendia a ler. Eu me lembro que uma vez, quando um aluno, no mês de outubro todos os alunos estavam lendo, somente ele não sabia, Ai um dia sentei perto dele e comecei a ler o que ele tinha feito de tema de casa e ele começou a juntar as sílabas, aquele dia eu chorei. Aquele dia... Sai correndo. E eu fiquei muito... Foi uma coisa que me marco muito sabe. A única coisa que me marco muito, que me lembro agora. Os alunos sempre me respeitaram muito. Ate hoje tem alunos que me chamam ainda de professora.

Para Solange, os medos mencionados referem-se à alfabetização, à disciplina em sala de aula, à diferença de idade dos alunos, à falta de materiais e livros. Ela destaca também o trabalho de planejamento coletivo com outras professoras na tentativa de suprir possíveis falhas:

O meu maior medo era a preocupação com a alfabetização. Ensinar a ler e escrever e a disciplinar, né, manter a ordem. Porque, meu Deus, há 30 anos atrás você tinha um regime bem, era tipo ditadura, os alunos tinham que vir em filas na sala de aula. Aqueles bancos de madeira que ia de dois alunos então tu não tinha como dispor na sala de aula diferente, né. Fazer uma dinâmica diferente na sala de aula. Era aquele ponto que tu tinhas que manter a disciplina. E até porque no início assim, as criança, tinha criança que vinha para a escola com mais idade, né. Tinha criança começava a vir para a escola com oito anos de idade. Sete, oito anos, nove anos. Tinha criança de treze, quatorze anos que estavam lá de primeira a quarta serie e você tinha que lidar com todas essas diferenças, isso na mesma turma. Então acho que esta era a maior preocupação, a preocupação de ensinar a ler e escrever para os novos. E manter essa disciplina e bem estar com todos. Era muita diferença de idade entre eles. Então imagina enquanto na primeira serie você ensinando lá as primeiras letrinhas, né, para a primeira serie. Enquanto as outras turmas já estavam alfabetizadas. Aí, muitas vezes, claro, eles paravam as atividades e ficavam observando o que os outros faziam, né. [...] Não dá para imaginar, hoje eu fico pensando, eu não consigo imaginar, como é que eu fazia, como é que eu dava conta de tudo isso. Muitas vezes para ajudar, assim, eu tinha livros, não tinha livros assim para as crianças. Não tinha como você dar uma atividade pronta. Sabe o que nós fazíamos? Tinha eu, a Salete, a Ivani, nós nos reuníamos para preparar aula. E a gente pegava aquelas folhas de carbono $e$ colocava no meio das folhas de oficio $e$ passava por cima, que daí nós, isso várias vezes, tudo à mão, para fazer algumas cópias assim, para dar uma atividade pronta, pro aluno só colocar, estudar, por a resposta, fazer um texto.

Em sala de aula, cada professora aprendia a ensinar com as experiências vividas enquanto alunas; portanto, os saberes docentes já estavam constituídos a partir de modelos postos anteriormente (TARDIF, 2002). As prefeituras de alguns municípios da região davam cursos, que serviam para melhorar o desempenho do professor 
em sala. Eles eram supervisionados por inspetores e deveriam estar com as atividades propostas em dia e registradas. Além de observar o caderno dos alunos, os inspetores questionavam as crianças para verificar o que elas estavam aprendendo.

Como as professoras não possuíam graduação, e no início da carreira não tinham condições de entrar em uma universidade, elas aprendiam por suas experiências. Criavam, pesquisavam e tornavam concreto o conhecimento que haviam adquirido na própria experiência como alunos.

\section{As múltiplas atividades}

Como a professora tinha muitos afazeres na escola, para além das aulas, eram necessários uma boa organização e planejamento, pois os alunos não podiam ser prejudicados pelas outras tarefas realizadas na escola. Nossas narradoras nos contaram um pouco como era a organização das atividades diárias que deveriam desenvolver como docentes. Destacaram a organização das atividades, a divisão de tarefas para cada série, as atividades extra-sala de aula, as múltiplas funções que desenvolviam como merendeira, faxineira, nas hortas, nos jardins, nas atividades religiosas nas comunidades. Vejamos o que elas narraram:

Sim, eu pegava por semana, porque não tinham muitos, no máximo dava uns 8 por série. Aí, tu pegavas a terceira, que esta semana ficava responsável pela limpeza, lanche e o pátio. Vamos dizer começava às dez e meia e eles faziam, e o restante ficava comigo na sala. Eles eram responsáveis, tu não te incomodavas, não precisava ir tantas vezes lá fora. (Ivani)

Eu usava assim aqueles que se chamava de diário de classe. Eu registrava tudo, até aquilo que eu utilizava na linguagem oral. Eu deixava tudo registrado, aquilo que eu iria falar para os alunos naquele dia. Talvez surgisse o assunto do dia, mas eu registrava tudo. Eu me sentia segura. Na escolinha que eu estava tinha dois quadros, então eu dividia para as turmas. Eu chegava sempre meia hora antes do meu horário para deixar tudo preparado para não perder tempo. [...]. Eu fazia assim, por exemplo, para não misturar muito o dia que eu dava português, para a terceira série, por exemplo, para a quarta série também. Às vezes, eu reforçava aonde eu sabia que a quarta série era um pouco mais fraca, daí com aquele conteúdo eu dava um reforço para a outra série já. Porque, às vezes, a gente notava que aquele aluno estava assim, que não tinha pegado bem aquela matéria, então eu selecionava assim. (Lucia).

Eu era professora, faxineira, merendeira, diretora, fazia todas aquelas papeladas. Como era o nome daquilo mesmo [...] Folhas de avaliação. Trabalhava com horta. Nas escolas isoladas eu sempre trabalhei com horta e eles levavam para casa alface, de tudo o que eu plantava. [...] Eu fazia assim, tal dia, segunda, quarta, sexta às onze e meia nós ia para a horta ou depois das onze nós ia para a horta. E a merenda nós ia fazer na casa da vizinha, porque na escola não tinha fogão. Eu dava atividades para as 4 turmas e corria lá fazer a comida. (Salete).

Às vezes, eu paro e penso, hoje com todos os recursos que a gente tem na escola, na sala de aula, eu fico pensando como a gente conseguia dar aula, né? Que nem no começo com as quatro séries na mesma sala, na mesma turma, $1^{a}, 2^{a}, 3^{a}$ e $4^{a}$ e aí aquela escolinha onde você tinha que ser professora, merendeira, fazia o lanche para as crianças, limpeza na escola, cuidava da horta e ainda a gente se envolvia com a comunidade. Era uma responsabilidade bastante grande. E a gente se virava. Às vezes, fico pensando e até falando com outras colegas, como é que a gente conseguia dar conta de tudo isso. [...] Que eu me lembro, tinha os conteúdos que eram comuns para todas as séries, como por exemplo, quando, você vai trabalhar com animais, então são conteúdos que você abrange na $1^{a}, 2^{a}, 3^{a}$ e $4^{a}$ séries, então a gente fazia um apanhado geral sobre, tratava o assunto, levava o conteúdo, todos participavam do conteúdo inicial e depois encaminhava, dava uma abordagem com cada série. Assim, as atividades eram diferentes para cada série, dependendo do grau de instrução de cada série. [...] Então, utilizava de carbono e nós sempre 
procurava se reunir, tinha outras colegas também. Nós sempre procurávamos fazer um trabalho coletivo, com planejamento. Nós planejamos as aulas, eu nunca fui para a escola assim, de chegar de mãos abanando e chegar lá para pensar lá na frente dos alunos o que trabalhar. Eu sempre levei minhas aulas planejadas, todas organizadas para cada série o que eu ia fazer. Eu acho que isso ajudava no andamento sabe! Se você chega ali e não sabe o que trabalhar? Aí vira bagunça! Então, tinha que ter tudo bem organizadinho. (Solange)

Só tinha um quadro negro e este era dividido em quatro partes, quando havia possibilidade havia um $2^{\circ}$ quadro de um metro, para determinar uma série. Tinha de fazer milagre, enquanto tentava alfabetizar a $1^{a}$ o que os outros fazem no mesmo tempo? [...] Ensinava a, e, $i, o$, u para os pequenos e enquanto eles faziam, vamos dizer, alguma coisa que eles tinham no caderno, tomava a leitura da segunda $e$ passava umas continhas, já planejadas pra a terceira, os da quarta liam um livro pra depois entrar em estudos sociais. [...] Eu tinha Livros textos, didáticos, depois planejava. Normalmente, não se conseguia passar o que planejava, visto que as quatro séries estavam no mesmo turno. Às vezes, planejava que iria passar um tipo de substantivo ou dois, acabava passando só um, pois o outro já não dava. [...] No quadro grande fazia 3 turmas e no outro era a $4^{a}$. [...] Nós tinha apoio da secretaria de educação do estado, vinha alguma coisa de material para pesquisa, material didático, livro texto do professor. [...] No início era somente no quadro, depois veio o mimeógrafo, aí passava as folhas uma a uma. Passava trabalhos mimeografados uma vez por semana, pois não conseguia desenvolver muita coisa. Ao mesmo tempo fazíamos merenda, limpeza, faxina, a horta era de nosso encargo na época a Acaresc acompanhava, não tinha ninguém para ajudar. [...] Nós programávamos, tal dia ia pra horta, depois no final da aula tirava para fazer limpeza, enquanto os alunos iam copiando, a gente ia pra cozinha fazer merenda. (Zeneci).
A partir das narrações observa-se então o que defende Guedin (2005 p. 135), "Os saberes da experiência não são saberes como os demais eles são formadores de todos os demais. (...) A experiência docente é espaço gerador e produtor de conhecimento, mas isso não é possível sem uma postura crítica do educador sobre as próprias experiências".

\section{Tempos de Dificuldades}

No Oeste Catarinense, o início das atividades formais de educação nas escolas multisseriadas foi marcante para os profissionais que passaram por essas salas de aula repletas de alunos de várias séries. Os profissionais que trabalhavam nessas escolas, geralmente, eram escolhidos para a profissão por necessidade de alguém que assumisse as atividades educativas na comunidade. Na época, décadas de 1950, 1960 e 1970, a princípio, não havia tantas opções de emprego, ser professor não significava privilégio financeiro, mas um meio de auxílio nas dificuldades que eram encontradas sob todos os aspectos.

Salete e Ivani destacaram como dificuldade a organização das atividades para as quatro séries, a falta de materiais básicos como folhas de papel para desenvolver atividades, a dificuldade de locomoção até a escola. Vejamos:

Foi difícil, porque eu sempre lecionei em séries inicias, de $1^{a}$ a $4^{a}$, e nos doze anos estive com quatro turmas juntas. E para cada série tinha um quadro, nos Rossete tinha dois quadros, daí eu repartia no meio, daí $1^{a}, 2^{a}$ e $3^{a}, 4^{a}$. Levava os caderninhos para casa. Eles sempre tinham dois cadernos, daí eu levava um para casa e preparava os temas para uma turma para não deixar a outra de folga e continuava as atividades, sempre primeiro para a $1^{a}$ serie e $2^{a}$. E ligeiro, né? Porque, quando tu terminavas lá, os primeiros já estavam sem atividade. Não foi fácil, doze anos eu trabalhei com quatro turmas. E sempre na base de 30, 35, 38, uma vez, eu lecionei com 47 alunos de $1^{a}$ a $4^{a}$ juntos, $1^{a}, 2^{a}, 3^{a}, 4^{a}$ serie, foi muito difícil. (Salete)

Sim, repartia o quadro em quatro, três mais porque a $1^{a}$ eu passava mais no caderno escrevia tudo no caderno, na época não tinha livros didático pra cada um não 
recebiam a gente não tinha um livro pra cada aluno só o professor recebia um livro. [...] Pouco, pouco, bem pouquinho, a gente tinha muita falta de material na época, mas a gente dava um jeito. [...] A gente foi até no Banco do Brasil pedir folhas que eles não ocupavam mais, aí a gente ocupava o verso, aí foi chegando o mimeógrafo, senão a gente passava tudo no quadro, aí a gente ia pedindo, um pouco a prefeitura mandava aquele papel jornal eu vi que ali na escola ainda tem aquela folha escura. Até que chegou as folha de oficio, mimeógrafo, né, quando cheguei aqui em Santa Lucia tinha isso, lá na linha Marcon não tinha não. (Ivani).

Esta narradora destacou também as peripécias que realizava para chegar até a escola e realizar o trabalho.

Nisso sim, essa parte era bem dificil porque no início eu saia seis e meia da manhã, chegava às sete no meu trabalho. Às vezes, esperava até às sete e meia na casa de um agricultor pra depois ir pro colégio porque era escuro ainda, depois que eu ia pra escola pra começar minha aula, daqui até a linha Marcon a gente ia de carona ou ônibus, o que se encontrava, né, eu e a Solange fazíamos esse trajeto juntas. Os últimos anos até tinha carro, mas pouco tempo. (Ivani).

Por sua vez, Lucia evidenciou os muitos quilômetros andados a pé para chegar até seu local de trabalho:

Para me deslocar não era tão longe, mas tinha muitos morros. Tinha muita pobreza, muita, que, às vezes, eu tinha que tirar do que eu ganhava, tirar do meu dinheiro para comprar material escolar para os alunos $e$ a angústia de ser nova, ficar longe dos pais, dos irmãos. Mas era o que eu queria. [...] Eu quero colocar que, assim, independente daquilo que eu ganhava eu pensava naquela profissão maravilhosa que era ensinar, porque era um dom divino também, né? Também eu pensava ai, meu Deus, eu ganho muito pouco eu vou largar mão por que é uma porcaria. Eu amava minha profissão, só que era muito... Muito sofrido.
Pouco meio de transporte, sem material $e$ eu caminhei dois anos eu fazia 14 quilômetros por dia. Quando eu comecei a lecionar pelo estado na Linha da Gruta. Caminhava da linha da gruta até ali onde mora o Gireli, dá sete quilometros pra ir e sete pra voltar e eu caminhava todo dia a pé, até que arrumei uma casa pra parar. E na casa que eu parava ajudava fazer as tarefas diárias, ajudava fazer tudo, até tirar leite eu ia e pagava pensão ainda. E, ainda tinha vontade de continuar, rezava muito pra mim, que quando chegava ofim do ano, uma época não tinha professora, eu era substituta como agora não é concursada na época diziam substituto, chamavam os professores que não tinham se efetivado. Mas eu rezava muito que queria continuar, até que depois eu me efetivei. Com dez anos de magistério eu consegui a efetivação no Estado. Efetivei-me como professora do Estado.

Zeneci também relatou as dificuldades para chegar à escola e como precisava organizar as atividades para todas as séries na mesma sala.

A maior dificuldade era o meio de transporte, era longe, tinha de ir a pé ou a cavalo, carona quando se tinha. Teve época em que tinha de fazer seis quilômetros. [...] Só tinha um livro e no início... As turmas eram todas juntas numa mesma sala. $1^{a}, 2^{a}$, $3^{a}$ e $4^{a}$ séries juntas. Tinha de ser milagrosa. Atender a primeira serie até alfabetizar, depois dar continuidade na segunda, na terceira um aprofundamento de estudos e na $4^{a}$, fazer entender que estavam a nível de $4^{a}$ série. Ter um bom jogo de cintura.

A formação profissional não representava uma condição para ser professor. A necessidade de ensinar uma criança a ler e a fazer contas não implicava uma maior formação para assumir as aulas; como professora, ela se tornava uma docente por suas próprias mãos. O profissional em sala estava se formando a seu modo. Geralmente, as comunidades, mesmo sabendo da não titulação dos professores, aceitavam-nos, pois não viam essa pessoa simplesmente como docente, mas como "pessoas vividas", que poderiam ensinar às crianças o que sabiam, ou seja, o que haviam aprendido 
enquanto alunas e durante sua vida.

\section{Costurando algumas ideias}

Considerando que cada professora constrói seus saberes a partir das relações que se estabelecem nos espaços de inserção, as diferenças pessoais, morais, éticas, religiosas, formativas dentre outras, instituem e ou fortalecem as especificidades e singularidades de cada personalidade/sujeito.

Desse modo, destacamos que os saberes docentes são constituídos de vários saberes vindos de diferentes fontes, o que implica um processo de aprendizagem e de apropriação no decorrer da formação pessoal e profissional durante a vida. Essa noção de saber é atribuída aos conhecimentos, competências, habilidades (ou aptidões) e às atitudes dos docentes, ou seja, aquilo que é chamado de saber-fazer e de saber-ser com o passar do tempo, o professor constrói saberes próprios. Assim, o desenvolvimento do saber é associado tanto às fontes e lugares de aquisição, quanto aos seus momentos e fases de construção. É importante lembrar ainda que os saberes docentes são abertos, estão em constante processo de qualificação, elaboração e revelação.

Evidencia-se nos depoimentos o papel de narrador como elemento unificador das comunidades, possibilitando pensar que "a narrativa não deve ser mais aquela do fluxo que justapõe eventos, mas aquela que produz interrupções, recortes no transcurso da história, de modo que o passado irrompe de um só golpe sobre o presente, originando uma situação de exceção" (CARDOSO JR, 1996, p. 55). A fonte das narrativas deve ser "a experiência que passa de pessoa a pessoa, a fonte a que recorreram todos os narradores. $\mathrm{E}$, entre as narrativas escritas, as melhores são as que menos se distinguem das histórias orais, contadas pelos inúmeros narradores anônimos" (BENJAMIN, 1994, p. 198).

A realização de pesquisas como esta, a partir das narrações de memórias, possibilita que os sujeitos, ao narrar, recobrem suas experiências, que não queiram mais apagá-las em busca do sempre novo. Trabalhar com narrativas de memórias numa perspectiva de diálogo permite que os narradores percebam que muitas das respostas que buscam estão presentes em suas experiências vividas e nas memórias.

Para não encerrar, lembro ainda que, Benjamin nos instiga a pensar como as memórias podem contribuir para o fazer-se dos sujeitos e, assim, problematizar a própria produção de conhecimentos quando se faz possível responder algumas perguntas como: em que medida as memórias de formação escolar, de experiências vividas, de construção como cidadãos, como profissionais, podem contribuir para que a academia passe a conhecer e respeitar os sujeitos comuns? Em que medida tais memórias e o ato de rememorar podem contribuir para o fortalecimento dos próprios narradores?

\section{Referências}

ARRUDA, José Jobson. O Sonho de História Que se Tem no Presente. In: DIEHL, Astor Antônio. Cultura Historiográfica: memória, identidade e representação. Bauru: EDUSC, 2002.

BOSI, Ecléa. Memória e Sociedade: lembranças de velhos. São Paulo: Companhia das Letras, $3^{a}$ ed., 1994.

BENJAMIN, Walter. Magia e técnica, arte e política. $7^{\mathrm{a}}$ ed. São Paulo: Brasiliense, 1994. (obras escolhidas vol. 1).

CARDOSO JR., H. R. Tempo e Narrativa Histórica nas "Teses" de Walter Benjamim. In: MALERBA, Jurandir. (Org.). A Velha História: Teoria, Método e Historiografia. Campinas-SP: Papirus, 1996. p. 51-60.

CHAUÍ, Marilena; FRANCO, Maria Sylvia Carvalho. Ideologia e Mobilização Popular. Rio de Janeiro: Paz e Terra, 1978.

ECKERT-HOFF, B. M. O dizer da prática na formação do professor. Chapecó: Argos, 2002.

D’ALÉSSIO, Márcia Mansur. Memória: leituras de M. Halbwachs e P. Nora. In: Revista Brasileira de História. São Paulo: ANPUH/Marco Zero v.13, n. 25/26, 1993, pp. 97-103.

DEPOIMENTO ORAL DE: Ivani Lazzari, 04/02/2009.

DEPOIMENTO ORAL DE: Lúcia Girelli Canelo, 27/01/2009. 
DEPOIMENTO ORAL DE: Salete de Col Ferrari, 06/02/2009.

DEPOIMENTO ORAL DE: Solange Canello Bandiera, 03/11/2008.

DEPOIMENTO ORAL DE: Zeneci Teresinha Lucca, 27/01/2009.

GHEDIN, Evandro. Professor Reflexivo: da alienação da técnica à autonomia da crítica. In: PIMENTA, Selma Garrido; GHEDIN, Evandro. Professor reflexivo no Brasil: gênese e crítica de um conceito. São Paulo: Cortez, 2002, p.129-150.

GÓMEZ, Angel Pérez. A cultura escolar na sociedade neoliberal. Porto Alegre: ARTMED, 2001.

LOWENTHAL, David. Como Conhecemos o Passado. In: Trabalhos da Memória. Projeto
História - n. 17. São Paulo: EDUC, 1998, p. 63201.

MEIHY, José Carlos Sebe B.; HOLANDA, Fabíola. História Oral: como fazer, como pensar. São Paulo: Contexto, 2007.

PAIM, Elison. Antonio. Memórias e experiências do fazer-se professor(a). Unicamp: Campinas, 2005 (Doutorado em Educação).

PINTO, Julio Pimentel. Os Muitos Tempos da Memória. In: Trabalhos da Memória. Projeto História - n. 17. São Paulo: EDUC, 1998, pp.203211.

TARDIF, Maurice. Saberes Docentes \& Formação Profissional. Petrópolis: Vozes, 2002.

THOMPSON, E.P. A miséria da teoria - ou um planetário de erros. Rio de Janeiro: Zahar, 1981.

\section{Sobre o autor:}

Elison Antonio Paim: Possui graduação em História pela Universidade Federal de Santa Maria (1986), mestrado em História pela Pontifícia Universidade Católica de São Paulo (1996) e doutorado em Educação pela Universidade Estadual de Campinas (2005). Professor Adjunto I da Universidade Federal de Santa Catarina (UFSC), lotado no Departamento de Metodologia de Ensino (MEN) do Centro de Educação. Tem experiência na área de História e Educação, com ênfase em Praticas de Ensino, Experiências de Ensino. Desenvolve trabalhos de Ensino, Pesquisa nos seguintes temas: estágio; formação docente; experiência, memória; fazer-se professor, história; historiografia; ensino de história, memória e patrimônio cultural.

Recebido em: 10/2013

Aprovado em: 06/2013 